\title{
Letter to the editor regarding "spatiotemporal association of low birth weight with Cs-137 deposition at the prefecture level in Japan after the Fukushima nuclear power plant accidents"
}

\author{
Sani Rachman Soleman ${ }^{1,2}$, Tomoko Fujitani ${ }^{1}$ and Kouji H. Harada ${ }^{1 *}$ (D)
}

\begin{abstract}
In the previous report, association between increased low birth weight prevalence and radiocesium deposition after 2011 Fukushima nuclear disaster was found. However, the statistical analyses therein raised several questions. First, ecological variables are not justified enough to adjust potential confounding. Second, the spatiotemporal regression model does not consider temporal reduction in radiation dose rate. Third, dose-response plot between dose rates and odds ratios overestimates $R^{2}$ and underestimates $p$ value.
\end{abstract}

Keywords: Low birth weight, Radiation, Epidemiology, Statistics, Ecological study, Fukushima nuclear disaster

\section{Dear Editor}

Regarding with a recent study on Cs-137 exposure with low birth weight (LBW) in infants in Japan by Scherb and Hayashi [1], we express concerns on data analyses, particularly in Figures 4 and 5 of the article.

Firstly, LBW can be influenced by various individual factors such as body weight change of mothers during pregnancy, smoking, etc. The authors included spatiotemporal effects in logistic regression model (but details of modeling were not provided), and analyzed data without individual factors. Authors included ecological variables, but they are not enough to control individual variations for LBW. How can annual population, number of physicians adjust the potential risk factors for LBW? In addition, if triple disasters affected those background factors, OR jump could be observed. Hence, individual risk factors are essential for the analysis because the observed OR for Cs137 is relatively small and easily influenced by confounding.

This comment refers to the article available at https://doi.org/10.1186/ s12940-020-00630-w.

* Correspondence: kharada-hes@umin.ac.jp

${ }^{1}$ Department of Health and Environmental Sciences, Kyoto University Graduate School of Medicine, Yoshida Konoe, Sakyo, Kyoto 6068501, Japan

Full list of author information is available at the end of the article

C The Author(s). 2020 Open Access This article is licensed under a Creative Commons Attribution 4.0 International License, which permits use, sharing, adaptation, distribution and reproduction in any medium or format, as long as you give appropriate credit to the original author(s) and the source, provide a link to the Creative Commons licence, and indicate if changes were made. The images or other third party material in this article are included in the article's Creative Commons licence, unless indicated otherwise in a credit line to the material. If material is not included in the article's Creative Commons licence and your intended use is not permitted by statutory regulation or exceeds the permitted use, you will need to obtain permission directly from the copyright holder. To view a copy of this licence, visit http://creativecommons.org/licenses/by/4.0/. The Creative Commons Public Domain Dedication waiver (http://creativecommons.org/publicdomain/zero/1.0/) applies to the data made available in this article, unless otherwise stated in a credit line to the data. 


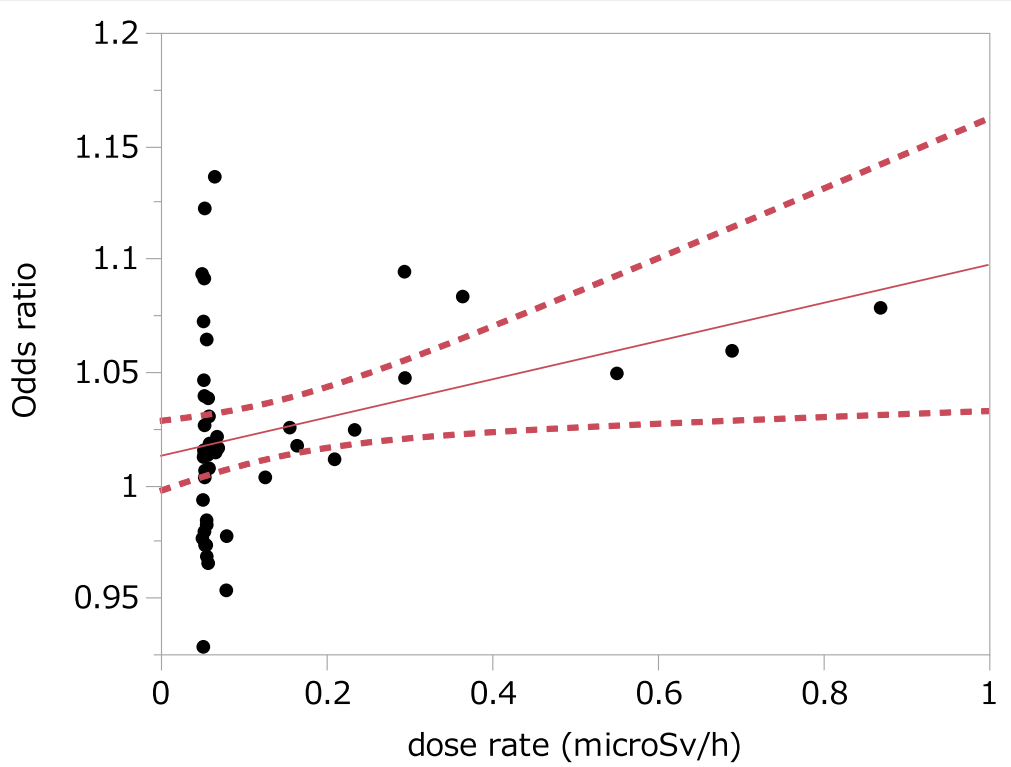

Fig. 1 Unrestricted linear regression analysis between dose rates and odds ratios in 47 prefectures in Japan shown in the report [1]. Red line showed regression line with $95 \%$ confidence intervals (dotted lines). $R^{2}=0.108$ and $p=0.0239$ for slope factor

Secondly, Figure 4 of the article claimed ionizing radiation increased the prevalence of LBW. The logistic model assumed the level-shift after 2011 persists to 2018 at same magnitudes. According to previously study [2], air radiation dose rate from deposited fallout was highest at initial time of deposition, but the dose decreased to less than $40 \%$ only by physical decay until 2016. Further, migration of radionuclide in soil reduced the dose rate to $20 \%$ of initial rate [2]. Thus, it is unlikely that the effect on Cs-137 persisted for years without any attenuation. In other words, observed OR jump can be attributable to other factors in triple disasters or regional trends.

Thirdly, we found an overestimation of $\mathrm{R}^{2}$ and underestimation of $p$ value of the regression in Figure 5 of the article. Authors mixed data of 37 prefectures into one point, and made variations of them small. As shown in Tables 2 and 3 of the article, even in non-contaminated regions showed high odds ratios over 1.1. Furthermore, authors analyzed them with restricted linear regression model (intercept was fixed to 1), but we examined them in unrestricted regression that showed $R^{2}$ of 0.37 and $p=0.046$. The $\mathrm{R}^{2}$ was further decreased to 0.11 in the analysis of original 47 records (Fig. 1 in this letter). Authors intended to 'avoid an overly scattered picture', but the manipulation caused overestimation of $R^{2}$. In addition, there was no rationale to employ restricted linear regression analysis.
According to explanations above, we suggest that authors will clarify the assumptions and rationale in the study.

\section{Authors' contributions}

SRS and KHH drafted the initial manuscript and TF reviewed the manuscript. All of them has approved the final form of this letter.

\section{Funding}

This correspondence was partly supported by a Grant-in-Aid for Scientific Research from the Japan Society for the Promotion of Science (JSPS) (Grant No. 19H01164).

Availability of data and materials

Data and material sharing are not applicable to this letter.

Ethics approval and consent to participate

Not applicable.

\section{Consent for publication}

Not applicable.

\section{Competing interests}

All authors declare that they have no competing interests.

\section{Author details}

${ }^{1}$ Department of Health and Environmental Sciences, Kyoto University Graduate School of Medicine, Yoshida Konoe, Sakyo, Kyoto 6068501, Japan. ${ }^{2}$ Department of Public Health, Faculty of Medicine, Universitas Islam Indonesia, Yogyakarta 55584, Indonesia.

Received: 27 August 2020 Accepted: 31 August 2020

Published online: 25 November 2020

\section{References}

1. Scherb H, Hayashi K. Spatiotemporal association of low birth weight with Cs-137 deposition at the prefecture level in Japan after the Fukushima nuclear power plant accidents: an analytical-ecologic epidemiological study. Environ Health. 2020;19(1):82. 
2. Saito K, Mikami S, Andoh M, Matsuda N, Kinase S, Tsuda S, et al. Temporal change in radiological environments on land after the Fukushima Daiichi nuclear power plant accident. J Radiat Prot Res. 2019;44(4):128-48.

\section{Publisher's Note}

Springer Nature remains neutral with regard to jurisdictional claims in published maps and institutional affiliations.

Ready to submit your research? Choose BMC and benefit from:

- fast, convenient online submission

- thorough peer review by experienced researchers in your field

- rapid publication on acceptance

- support for research data, including large and complex data types

- gold Open Access which fosters wider collaboration and increased citations

- maximum visibility for your research: over $100 \mathrm{M}$ website views per year

At BMC, research is always in progress.

Learn more biomedcentral.com/submissions 